This item was submitted to Loughborough's Research Repository by the author.

Items in Figshare are protected by copyright, with all rights reserved, unless otherwise indicated.

\title{
Aphra Behn and the verse epistle
}

PLEASE CITE THE PUBLISHED VERSION

http://dx.doi.org/10.1080/09699080903161973

PUBLISHER

(C) Routledge (Taylor \& Francis)

VERSION

AM (Accepted Manuscript)

LICENCE

CC BY-NC-ND 4.0

REPOSITORY RECORD

Overton, W.J.. 2019. "Aphra Behn and the Verse Epistle". figshare. https://hdl.handle.net/2134/5724. 
This item was submitted to Loughborough's Institutional Repository (https://dspace.lboro.ac.uk/) by the author and is made available under the following Creative Commons Licence conditions.

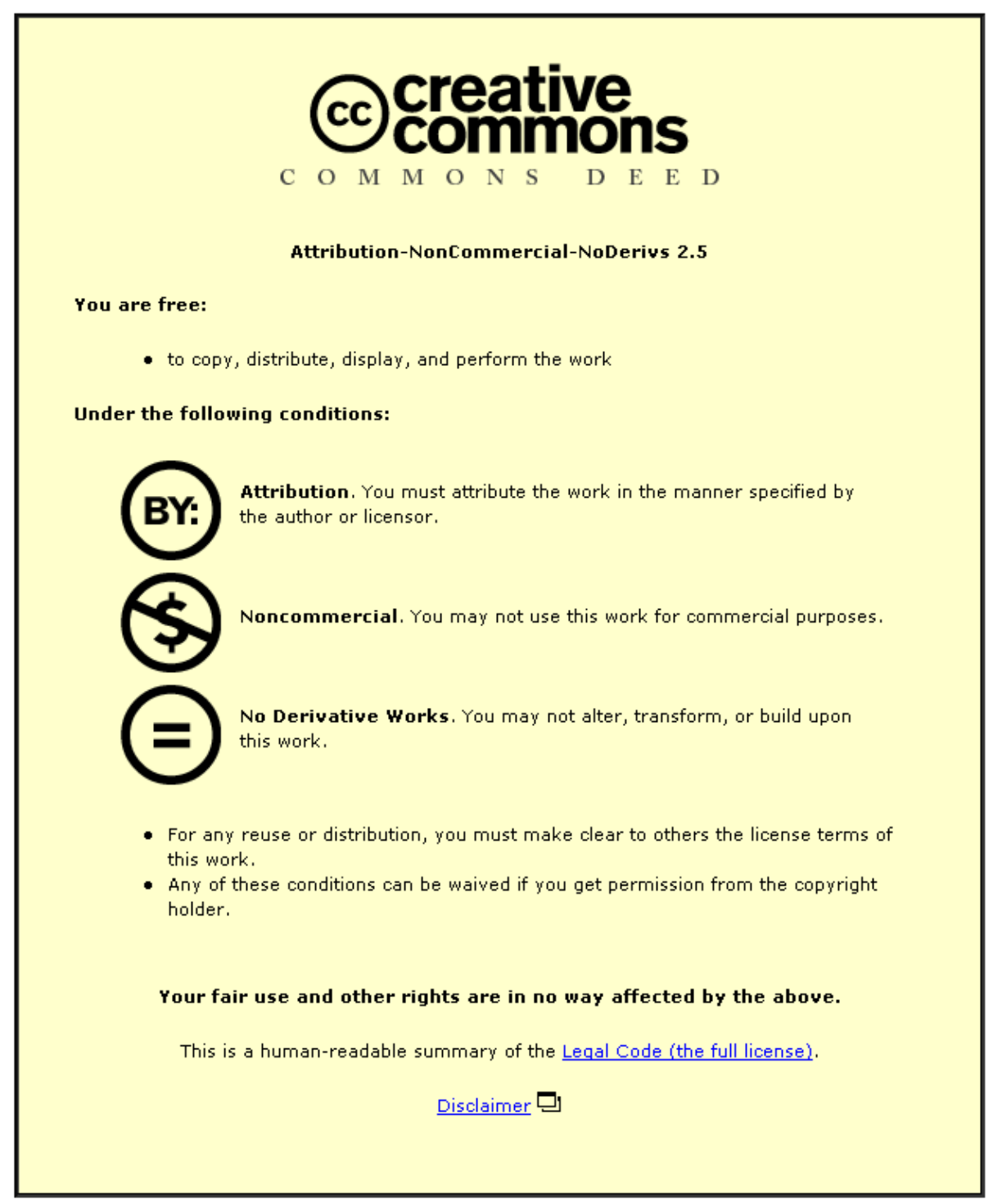

For the full text of this licence, please go to: http://creativecommons.org/licenses/by-nc-nd/2.5/ 


\section{Bill Overton}

Aphra Behn and the Verse Epistle

The verse epistle is a key eighteenth-century form that developed in the Renaissance but gained critical mass only during the Restoration. Despite increasing scholarly attention to the work of Aphra Behn, including her poetry, her verse epistles remain relatively little discussed, and the role she played in establishing the form has not been recognized. Once Behn's contributions to the form are identified, their importance in her work, as measured both by their number and their quality, becomes clear, especially when compared with the work of other writers of her period. She produced examples both of the Horatian familiar epistle, and, in “Oenone to Paris”, a striking rewriting of an Ovidian heroic epistle, along with amatory epistles, satirical epistles, and one complimentary epistle. Not only are her verse epistles important in their own right, but they influenced other writers, male and female. They are particularly distinctive for the turn she gave, as a woman writer, to a form previously practised chiefly by men.

The verse epistle has a long history. While it stems from Horace and Ovid in ancient Rome, in English literature it began to flourish in the Elizabethan and Jacobean periods and had its heyday in the eighteenth century. But there is an odd hiatus in its development. Reviving across Europe in the Renaissance, its first real arrival in English was in the work of Sir Thomas Wyatt ${ }^{1}$, though it cannot be said to have gained full recognition until the 1590 s. That decade saw Drayton's publication of Englands Heroicall Epistles, and the writing of various epistles by Daniel and Donne. Jonson and other poets soon followed their examples. While Drayton's model was the Ovidian heroic epistle, Donne and, a little later, Jonson embraced 
the Horatian tradition of quasi-familiar and often discursive epistles to friends and patrons; Daniel contributed examples of both types. ${ }^{2}$ These different kinds of epistle constitute a significant part of Drayton’s, Donne’s and Jonson’s output, and to a lesser extent of Daniel's. Englands Heroicall Epistles runs to 24 poems in its final version, while Donne wrote over 40 verse epistles and Jonson 13 poems entitled “Epistle” along with much other familiar verse that could be defined as epistolary. ${ }^{3}$ Yet the form then stalled. None of the major poets of the next generation cultivated it - not Milton, Cowley nor Marvell, nor even Waller - though it was kept alive in the work of figures such as Alexander Brome and Charles Cotton and in occasional poems by, among others, Hugh Crompton and Anne Bradstreet. ${ }^{4}$ Instead, it was writers of the Restoration who succeeded in establishing the verse epistle, and to such effect that it became one of the key poetic forms of the following century. A writer who played an important but little recognized role in this development was Aphra Behn. ${ }^{5}$

One reason why Behn's verse epistles have attracted relatively little discussion is that the form is difficult to define. It is important to begin, then, with some idea as to what a verse epistle is and how it was understood in the period. Fundamentally, a verse epistle is a letter in verse form, but this has two important corollaries that stem from Horace and Ovid and that have long been established. First, there are two kinds of Horatian epistle, the familiar letter and the verse essay addressed to a friend or patron. Because these are intended to resemble familiar communications, their diction and verse form are usually fairly plain. In the case of verse form, this means that such epistles are rarely stanzaic. In Britain, the two most common forms for Horatian epistles are iambic tetrameter and iambic pentameter couplets; the Scots form of the Standard Habby, established for the verse epistle by Allan Ramsay and William Hamilton in the early eighteenth century, and consisting of six-line stanzas, is an interesting exception. ${ }^{6}$ Second, the Ovidian or heroic epistle is almost always in heroic couplets - which 
means, of course, a stylized form of iambic pentameter couplets in which the couplets are typically closed and, especially during the Restoration, sometimes extend into triplets with closing alexandrines. These devices go along with a wider stylistic range than that of the Horatian epistle, in keeping with the passionate emotional register.

Behn produced epistolary verse both in the Horatian and the Ovidian form. The most obvious example of the latter is her free version of Ovid's “Oenone to Paris”, but she also wrote a satirical heroic epistle, "Ovid to Julia”. ${ }^{7}$ Most of her verse epistles, however, are Horatian. At the familiar end of the spectrum are "A Letter to a Brother of the Pen in Tribulation”, “A Letter to Mr. Creech at Oxford, Written in the last great Frost”, and “To Damon. To inquire of him if he cou'd tell me by the Style, who writ me a Copy of Verses that came to me in an unknown Hand". ${ }^{8}$ At the formal end are "To my Lady Morland at Tunbrige”, “To Mrs. Price”, and the unfinished "VERSES design'd by Mrs. A. Behn, to be sent to a fair Lady, that desir'd she would absent herself, to cure her Love". ${ }^{9}$ In between are the satirical epistles “A Letter to the Earl of Kildare, dissuading him from marrying MOLL HOWARD” and “To Poet Bavius"; while on the margins, as it is such an odd work, is her free translation "A Voyage To The Isle of Love". ${ }^{10}$ That is a total of 11 poems out of the 99 in Janet Todd’s edition of her verse, not including “A Satyr on Doctor Dryden”, an invective that could be described as epistolary of which Behn's authorship is uncertain. ${ }^{11}$ It is important to note that, except for “A Voyage To The Isle of Love”, which is a kind of medley, all are in couplets of iambic tetrameter or, more often, pentameter.

Yet Behn also wrote other poems that have a claim to be considered as epistolary. In particular, in her selection of Behn's poetry, Janet Todd includes a section entitled "Verse Epistles” that contains six poems I have not mentioned. ${ }^{12}$ The first two of these are clearly not verse epistles. One is “Our Cabal”, which cannot be an epistle as it has no addressee, 
although, as an example of the genre of coterie verse to which several of Behn's epistles belong, it invites inclusion with them. The other is “To Mrs. W. On her excellent Verses (Writ in Praise of some I had made on the Earl of Rochester) Written in a Fit of Sickness”. ${ }^{13}$ This is a complimentary poem rather than an epistle because its style is elevated and its form that of an irregular ode. The question whether or not the other four poems can be considered as epistles is more challenging. Two I would rule out, because they are in stanzas. These are “To Lysander, who made some Verses on a Discourse of Loves Fire”, and "To Lysander, on some Verses he writ, and asking more for his Heart then 'twas worth”. ${ }^{14}$ Adopting a term from Harold Love’s edition of Rochester, I would call these "Love Elegies”. ${ }^{15}$ The reason why they might be read as epistles is that they are directed to a named addressee, but the same is true of much amatory verse and of many odes. Love's term is useful because it reflects the derivation of this type of poem from classical poets such as Ovid, Propertius and Tibullus. The reason that stanza form is crucial is that it stems from a tradition of song that is central to the ode, whereas tetrameter or pentameter couplets organized into verse paragraphs are much closer to the conventions of the prose letter.

But two of the poems in Todd's selection blur the boundaries between love elegy and verse epistle. These are "To Lysander at the Musick-Meeting”, and "To the fair Clarinda, who made Love to me, imagin'd more than Woman” ${ }^{16}$ Both are love poems, but both employ a fairly plain style and both are in iambic pentameter couplets. They may be compared with the two poems in the same verse form among those by Rochester classified by Harold Love as love elegies, “The Discovery” and "Could I but make my wishes insolent”, ${ }^{17}$ though neither has any of the elegance or sophistication of the two by Behn. I suggest that the four poems represent an emergent form, that of the amatory epistle - one of the assorted epistolary variants to develop during the long eighteenth century. If the two by Behn are 
added to her tally of verse epistles, the total, not counting “A Satyr on Doctor Dryden”, rises to 13 .

It may be argued that the kinds of distinction I am applying are anachronistic. Such an objection has some validity, but it overlooks two important justifications. First, the period in which Behn wrote was one of great creativity and so of rapid change in literary forms and conventions. Only from a post-eighteenth century vantage point is it possible to look back and recognize the emergence in the Restoration of variants of epistolary form that did not become firmly and distinctly established till later. Hindsight of this kind is crucial to demonstrating what a writer such as Behn achieved, because it illuminates the nature of her formal experimentation and the foundation it helped to provide for later developments. Second, distinguishing between different kinds of writing helps illustrate not only the formal richness and variety of verse in the period, but also its social context. Writers did not experiment with poetic forms in a vacuum. They did so as they vied with each other in a culture based largely on manuscript circulation, in which poems ran the generic gamut from satirical attack to compliment and panegyric, and in which readers outside the circle might be addressed explicitly or by implication. Epistolary verse in the Restoration grew in a culture of coterie writing. To understand how it spread, it is necessary to recognize the variety of epistolary forms it produced.

Distinguishing between different kinds of epistolary verse, then, helps bring out Behn’s contribution to the form as well as providing further evidence of her astonishing versatility. She had begun her career as a professional writer in the theatre, becoming arguably the most successful dramatist of the Restoration. Then, in the 1680s, she helped pioneer prose narrative in such extraordinary works as Love-Letters Between a Nobleman and his Sister (1684-87) and Oroonoko (1688). Yet she also wrote and published verse throughout her 
writing life in a wide range of different forms and genres. Excluding the epistolary verse I have mentioned, the 99 poems in Todd's edition of her Works include 25 songs, 17 poems of commendation or panegyric, 12 love elegies, 5 elegies, 4 pastoral dialogues, 3 prologues and 2 epilogues, 2 odes, 2 epigrams, 1 satirical dialogue, 1 epitaph, and 11 poems that adapt, paraphrase, translate or imitate different kinds of original. But the 13 epistolary poems (still not counting “A Satyr on Doctor Dryden”) represent a higher proportion of epistolary verse than in the work of any other poet of the period. For example, among the 82 poems accepted by Harold Love as probably by Rochester, only 5 can be counted as epistles, and 4 of these are mock-epistles that are essentially satirical. ${ }^{18}$ Even Dryden produced few verse epistles, as most of his poems that have been termed epistles are commendatory verses, most often printed with the works they praise. The sole clear examples of epistolary verse by Dryden are the verse letter he wrote for the Earl of Middleton to Etherege, and his translations of three of Ovid's Heroides. ${ }^{19}$ Instead, it is only female poets - Jane Barker and Mary Mollineux - who compete for epistolary honours with Behn. Both, however, wrote a little later than she did, and both have a much more limited range, Barker specializing in familiar and advisory epistles, Mollineux in moral and religious. ${ }^{20}$ Behn therefore stands out as a poet who wrote a larger number and variety of epistolary poems than her peers, and earlier, too, in the period. In discussing them I will begin with those that are closest to genuine letters, because this type is most typical both of the form and of the coterie verse that in this instance produced it. ${ }^{21}$

The only familiar epistle by Behn to have attracted much comment is "A Letter to a Brother of the Pen in Tribulation”. It is a lively, amusing poem, but also a compelling example of Behn's ability to take on a different voice - here a masculine one. The tribulation of the title results from venereal disease and its treatment, which included a sweating-tub and a harsh diet. Behn commiserates humorously with the sufferer, adopting, as Elizabeth 
Spearing puts it, "with great gusto the verbal costume of a man of the world, swearing with the best of them”. ${ }^{22}$ Yet at the end of the poem she implicitly alludes to the fact that she is writing, as it were, in drag. When she begins the final verse paragraph with the words "Now I could curse this Female” (41), both her addressee and any member of the coterie round which the poem circulated would have been aware of the fact that, though its style is a man's, its writer was a woman. Paul Salzman marks the distinction neatly by remarking that in this poem Behn "takes the masculine tone, but not the masculine voice", ${ }^{23}$ as in these lines her reasons for not cursing her addressee’s undoer are ironic and ambiguous. The line "She needs it not, that thus cou'd handle you” (59) probably means that a curse is needless because the woman is, of course, already poxed. Instead, Behn urges her friend to curse as a caution to other young men and as a way of removing altogether the evil from which he suffers. But her encouragement to "Curse till thou hast undone the Race" (48) is ambiguous. While the context suggests the race of prostitutes, or even of women, it could also mean "the human race”, in which case she is urging her addressee ironically to let his indignation rip while reminding him of his folly and mocking his discomfiture. ${ }^{24}$ This third meaning is the more likely because in the two previous sentences she has declined to curse a member of her own sex.

"A Letter to a Brother of the Pen” is also significant not only as an example of coterie verse but of the attraction of such verse to a growing reading public. The point is clear from the three marginal notes in the printed version (no manuscript copy survives). The circle of friends and acquaintances among whom, it is reasonable to assume, the poem first circulated would not have needed to be told that Behn's addressee suffered his bout of pox in Lent (“this holy time”, 5), why she among others "had greatest need” of him ("I wanted a Prologue to a Play", 14), or what his excuse was for laying low ("He pretended to retire to write”, 
facing line 23). Such confidences extend to the reader of the printed version the same privilege of belonging to a group of friends in the know that the manuscript copy would have taken for granted. As Judith Kegan Gardiner remarks, by publishing such a poem Behn “invites us as outsiders to be provisional members of this inner community or to enviously define ourselves by our exclusion”. ${ }^{25}$ Not least because the poem is so amusing, the former response is much more likely. The kind of invitation Gardiner describes is important, because it helps account for the popularity of the form in the following century when the market for verse grew considerably. Indeed, a poem originally written for a single addressee, though probably also intended for circulation among a coterie, becomes marketable to the extent that it may be understood and found entertaining or interesting by a much wider readership. Its appeal to such a readership is in part that it flatters its members with a kind of virtual association with the group of wits to which Behn and her friends belonged. Janet Gurkin Altman's concept of “addressee-consciousness” ${ }^{26}$ helps discriminate between a widening circle of explicit or implicit addressees. At the centre is the original addressee, further out is the coterie around whom the poem probably circulated, and on the periphery are readers who have no direct connection with them whatever, extending from the many buyers of the first printed copies to readers in later periods. The fact that the addressee of "A Letter to a Brother of the Pen" is not named would have added piquancy, though in different ways for members of the coterie, who would have known perfectly well who was meant, than for those outside it, whose pleasures are those of speculation. ${ }^{27}$ As William C. Dowling has shown, the implicit invocation of an external reader is central to the culture of the eighteenth-century verse epistle. ${ }^{28}$ Although Dowling's main concern is with the discursive epistle, the same principle holds true, for different reasons, with its familiar cousin. Behn’s familiar epistles both illustrate it very well and may also have set a precedent for other writers to publish verse 
of this kind.

While "A Letter to a Brother of the Pen" mocks another, in “A Letter to Mr. Creech at Oxford, Written in the last great Frost”, Behn's banter is directed chiefly at herself. The poem is an apology for not having been able to deliver an invitation that would have enabled her to meet Creech and introduce him to her friend and former lover John Hoyle, an admirer of Lucretius whose De Rerum Natura Creech had translated. It is self-mocking partly because Behn respects Creech, and partly because she is telling a story against herself about a farcical accident in the icy London streets in which her coach had been overset. Unlike "Letter to a Brother of the Pen", which is in plain pentameter couplets, it is in Hudibrastics - jaunty tetrameters with many end-of-line hypermetrical light stresses and comic, often forced, rhymes. This helps give the poem its humorously rueful tone, as when she rhymes "Nonsense” with “Tonson's” (4-5), or "Scarlet” with "Pilgarlick” (39-40). Yet, just as in the other poem, the tone is thoroughly masculine. Examples are what she says about having had too much to drink: "Because it being cold, you know, / We warmed it with a Glass - or so" (10-11), or her description of herself after the accident:

Who saw me could not choose but think,

I look’d like Brawn in sowsing drink.

Or Lazarello who was show'd

For a strange Fish, to’th’ gaping Crowd. (67-70)

The poem, too, makes clear that it is a proper letter by ending with a postscript. This is the only postscript in Behn's epistles, and it also stands out for the companionly warmth and affection it expresses. Asking Creech to pass on her regards to a friend to whom he had introduced her previously, she ends with a compliment that manages to be both colloquial and, enclosed as it is in a triplet, stylish: "Tell him how much - yet do not too, / My vast 
esteem no words can shew; / Tell him - that he is worthy - you” (94-96).

In "A Letter to a Brother of the Pen" and "A Letter to Mr. Creech at Oxford”, Behn adopts a form coded as essentially masculine on its own terms, asserting equality with her addressees as a fellow writer. In four other examples, however, she turns the form to conventionally feminine purposes. "To Damon. To inquire of him if he cou'd tell me by the Style, who writ me a Copy of Verses that came to me in an unknown Hand" announces its subject in its title. Here Behn presents herself as unequivocally female, asking a close male friend to identify the writer of an anonymous poem that has aroused not only her curiosity but her desire. She expresses the fluctuating emotions that the poem has excited in part through formal variations. While the poem's staple metre is iambic tetrameter couplets, they are very different from those in the verse letter to Creech. Not only are there no extra light stresses or comic rhymes, but on two occasions in the first verse paragraph she switches for four lines from couplets to alternating rhymes; she introduces triplets at key points (the end of the second verse paragraph, where there are two consecutively, and at the start of the last); and she lengthens 10 of the 95 lines to pentameters. This is a bold stylistic experiment, and it works very well to convey the ferment of emotion produced by the anonymous poem.

Judith Kegan Gardiner has called the type of verse I have discussed so far "fraternal poetry”, suggesting that in “To Damon” the speaker seems to share with her addressee "an easy camaraderie that is itself free of sexual tensions and full of mutual confidences”. ${ }^{29}$ Yet Behn also wrote the love elegies to men that I have mentioned, including the two that are epistolary, and three more formal verse epistles to women. The most elaborate of the verse epistles to women, which are all in iambic pentameter couplets, is “To my Lady Morland at Tunbrige”, a complimentary epistle that also manages to offer not wholly disinterested advice. ${ }^{30}$ As befitting a poem of compliment, its style is more elevated than that of the three 
familiar epistles to men. It begins, for instance, with an extended simile presenting its addressee as a conquering hero that takes up 12 lines before vehicle gives way to tenor; there are two consecutive triplets halfway through its 50 lines; and these triplets coincide with a change of tone from admiration to arch humour. It had been in a church that Lady Morland made such an impression on Behn and others, and Behn remarks that the priest "Forgot the Gospel, and began to Pray” (27; in other words, lost his place in the service), before capping this with the further comment that the congregation was so "Enamoured" that it "Neglected the mistake o' th' Love-sick priest” (28-29). This brings her to the advisory part of her epistle, which consists in recommending her addressee to outdo other women "In Cruelty as well as Beauty” (34), especially in response to Amyntas who has been unfaithful to Behn herself - implicitly with none other than Lady Morland. The advice is couched in terms that tread a fine line between flattery and impertinence. On the one hand, Behn suggests, Amyntas represents used goods, so that a "Slave" (44) who has already been hers should not be acceptable to her addressee. On the other hand, Lady Morland deserves "A Virgin-Heart” (47), and only this will show that she is truly as extraordinary as she appears: "And own a Soul as Great as you are Fair” (50). It is a very skilfully turned message, paying its addressee all possible tribute yet hinting, at the same time, that the rival she has eclipsed is potentially dangerous and that the favour she is enjoying may prove temporary.

Because it is unfinished, it is difficult to comment on “Verses design'd by Mrs. A. Behn, to be sent to a fair Lady”. It is possible, however, that the message here would have been more sisterly, for Behn uses the first person plural - "our bleeding Veins” (13) - to identify the pain she is suffering as a shared evil for women. She also compliments her addressee in a way that does not appear barbed, and she concedes that her addressee's diagnosis of her lovesick condition is accurate. "To Mrs. Price" is much more clearly a poem 
of female companionship. It is a graceful invitation to join the writer at Oxford, exploiting the familiar topos of rural calm versus urban and courtly trouble, and ending by offering to share what Behn calls “the Pleasures I count only mine” (22). The sisterly note is especially significant, for it feminizes a form that, from the time of its establishment by Horace, had always been essentially masculine. As her more conventional familiar epistles show, Behn could play the man’s role too, if often with her tongue in her cheek. In “To Mrs. Price”, however, her emphasis on a pastoral setting creates a female space of peace and retirement. But she makes a more radical shift still in her rewriting of Ovid’s epistle from Oenone to Paris. This, I will argue, is Behn's most striking contribution to the tradition of the verse epistle. To demonstrate the quality of her adaptation, and to bring out its key implications, requires extended and detailed discussion, especially because she alters her source at every level.

The poem first appeared in 1680 as “A PARAPHRASE ON OENONE to PARIS” in Tonson's influential and much-reprinted Ovid's Epistles, Translated by several Hands. ${ }^{31}$ As Dryden recognized in his Preface, it is a much freer version of the original than any of the other 23 poems of the collection (two of them alternative versions of different epistles). ${ }^{32}$ For this reason, it is the only poem to which he refers specifically, distinguishing it as an “imitation” like Cowley’s versions of two odes by Pindar and one by Horace that he has already mentioned (441; 248-50). Earlier in the Preface, he had introduced his distinction between three different kinds of translation: “metaphrase, or turning an author word by word, and line by line, from one language into another” (234-36); “paraphrase, or translation with latitude, where the author is kept in view by the translator, so as never to be lost, but his words are not so strictly followed as his sense, and that too is admitted to be amplified, but not altered" (238-42); and "imitation, where the translator (if now he has not lost that name) 
assumes the liberty not only to vary from the words and sense, but to forsake them both as he sees occasion; and taking only some general hints from the original, to run division on the ground-work as he pleases” (243-48). The fact that, ignoring Dryden’s definition, Behn’s poem has the word "paraphrase" in its title, rather than "imitation", may be explained by Carol Barash's remarks that “English women poets often used the word 'paraphrase' in the titles of their translations from various sources", and that, in this context, the word "suggests distance and lack of cultural authority (i.e. that another author had translated the text out of its original language and form)”. ${ }^{33}$ Dryden accounts for Behn’s freedom by adding: "I was desired to say that the author, who is of the fair sex, understood not Latin. But if she does not, I am afraid she has given us occasion to be ashamed who do" (441-44). His compliment is not necessarily to be read as mere gallantry. Although subsequent editions of Ovid's Epistles insert, before Behn’s, a version by John Cooper that is much closer to the original, ${ }^{34}$ her poem has strengths that are its own.

Dryden is known to have used several earlier translations of Ovid's Heroides. ${ }^{35}$ Whether or not Behn had access to any of these, to a prose version, or, possibly, to a version in French, ${ }^{36}$ she reimagined the entire situation of Ovid's poem. A rough idea of the extent of her changes may be gained by comparing the length of her poem with that of the original and with other translations. As Latin is a conciser language than English, it is not surprising that all the translators use more lines than Ovid. Cooper needed 182, as against the 158 of the original, whereas the closest modern verse translation, by Harold Isbell, takes 190; another modern version, by Daryl Hine, keeps the line-count down to 162, but only by cutting some corners with the sense. ${ }^{37}$ Behn's poem, inspired by the original but not moulded upon it, is all but twice as long at 314 lines - and nearly three-quarters as long again as Cooper's. In order, however, to recognize how far the poem she produced parts company with the original 
and strikes out on its own, it is necessary to identify the changes she made to Ovid's story, and to its whole tone and tenor.

The “Argument” prefacing Behn’s poem (later Cooper’s, placed before hers) sets out what would now be called the back-story. This begins with Paris cast out while a baby by his father Priam because of a prophecy that he would destroy Troy. Fostered by shepherds on Mount Ida, instead of perishing in the wilderness, Paris had met and fallen in love with Oenone before his royal identity was discovered. Behn's first change to this basic situation is to lower her heroine’s rank. ${ }^{38}$ Whereas Ovid's Oenone claims descent from a river-god, enabling her to assert not only that her status was much higher than that of Paris when they first met, but also that she is as entitled to royal dignity as he, ${ }^{39}$ Behn's presents herself not as a river-nymph but as “a Shepherdess” and “harmless Neighbouring Cottager” $(11,31)$. This also influences the tone of Behn's epistle, which has none of the pride and resentment of Ovid's. Second, and equally important, Behn makes Oenone and Paris lovers but not, as in Ovid, wife and husband. Ovid has Oenone pointedly repeat that she married Paris - contenta marito, “content to wed” (9), servo nubere nympha tuli, “deigned to wed a slave” (12) - and also refer to herself twice with the word uxor, or wife $(80,108)$. Instead, Behn emphasizes a code of honourable love. She does so as part of a larger contextual shift, for she uses the rural setting in which the love affair takes place to develop pastoral themes. This third move is significant in two main ways. On the one hand, it enables her to exploit fully the associations of pastoral with the Golden Age - a subject that she often engages with in her verse, not least in her eponymous adaptation ${ }^{40}$ - so that, for example, Oenone can plead: “'Tis false and broken Vows make Love a Sin, / Hadst thou been true, We innocent had been” (282-83). On the other hand, it enables her to contrast what she presents as the innocence and freedom from corruption of pastoral life with the dishonesty and cruelty of the court. Janet Todd has 
suggested that this aspect of Behn’s poem has political implications: "her Paris seems as much attracted by royal status as by Helen; a Stuart prince in exile, he cannot resist the lure of restoration" ${ }^{41}$ Within the poem, the effect of Oenone stressing Paris's royal status is to highlight the gulf between them. But it also enables Behn to set out an alternative system of values that she frames here and elsewhere, as in "To Mrs. Price”, as feminine. ${ }^{42}$

The fourth main change that Behn makes to the situation presented in Ovid is twofold. First, she has Oenone recall in much more detail the fatal scene in which Paris had to choose which of Juno, Minerva and Venus was the most beautiful. Her Oenone gives a closer account of the myth than Ovid's, providing fuller description and stating Venus's bribe, omitted in Ovid, explicitly: "the choice / Of all the fairest Greeks" (109-10). ${ }^{43}$ However, consistently with other changes in tone, Behn omits what Peter Knox calls the "bitter tone" of Oenone’s “insult” to Minerva in the remark that she would have looked better in her customary armour. ${ }^{44}$ Like Ovid's epistle, Behn's omits the part of the story in which Paris returns to Troy and has his royal identity discovered. But here she makes two subordinate changes. In her poem, unlike in classical legend, it is "the envying Gods" who "Declare [Paris] Great” $(121,122)$, soon after the beauty contest; and she has Paris sail not to Sparta, as in Ovid, but to Troy itself. As there was no sea between Mount Ida and Troy, such a voyage defies geography. Whether or not Behn knew this, the effect is to alter the nature of Paris's crime in a way that suits the poem's other emphases. Oenone represents him as promising her to raise her to his own rank once he has claimed it: "If Paris lives his Native Troy to see, / My lovely Nymph, thou shalt a Princess be!” (135-36). Because he fails to honour his promise, and returns with Helen instead, his betrayal is all the more flagrant. The other way in which Behn alters the initial situation concerns the point in the relationship between Oenone and Paris at which the epistle is written. A dramatic passage near the end of 
Ovid’s poem has Oenone recalling Cassandra’s prophecy that “A Grecian heifer is coming to ruin you, your fatherland and your home!” (117-18), and the poem ends with her regretting that the medical skills given her by Apollo cannot cure her of love. Both passages allude to the story's tragic ending, in which Oenone first refuses to heal the mortally wounded Paris and then relents too late. Both are entirely omitted by Behn. While her epistle, like Ovid's, is also set after Paris's return with Helen, she ends it with Oenone appealing to Paris to return, though also with a warning if he does not: “Turn then fair Fugitive, e're 'tis too late, / E're thy mistaken Love procures thy Fate” (310-11). The result is to play down the ominous prolepsis of the original, and to emphasize instead, in a long passage added wholly by Behn, the pastoral values that Paris has betrayed.

The detailed differences between Behn's poem and Ovid's are so extensive that it is pointless to try and document them fully. Instead, analysis of Behn’s opening lines, her key themes, and her presentation of Paris and Helen, should bring out most of their scope and impact. Behn’s Oenone begins like this:

To thee, dear Paris, Lord of my Desires, Once tender Partner of my softest Fires;

To thee I write, mine, whilst a Shepherds Swain, But now a Prince, that Title you disdain.

Oh fatal Pomp, that cou'd so soon divide

What Love, and all our Vows so firmly ty'd!

What God our Loves industrious to prevent, Curst thee with power, and ruin'd my Content?

Greatness which does at best but ill agree

With Love, such Distance sets 'twixt Thee \& Me. (1-10) 
Carol Barash remarks that, in contrast to Ovid's epistle, which emphasizes Paris’s act of reading, Behn's emphasizes Oenone’s act of writing. ${ }^{45}$ Crucial though this is, it is the tonal contrast between her lines and Ovid's that is most immediately striking. In the Latin, Oenone opens abruptly, omitting any form of salutation in a bitter, jealous reproach rendered effectively and fairly accurately by Cooper, his reversed first foot imitating the quantitative pattern of Ovid’s opening dactyl: “Read this, (if your new Bride will suffer) read”. ${ }^{46}$ Behn has Oenone not only greet her addressee, but greet him with ardour and affection. ${ }^{47}$ For her, Paris is not only "dear”, but "Lord of [her] Desires" - a brilliant oxymoron that asserts her stake in an erotic partnership in which she characterizes her role with a further oxymoron, "softest Fires", while delicately suggesting, in the phrase "Once tender", that it is he who has failed it. Adding briefly to that hint by declaring that he now "disdain[s]" to be hers, she then critically shifts the blame. For this Oenone, what is at issue is not Paris's betrayal of a wife who had stooped to marry him and who, in her eyes, is not his inferior even after his royal status has been discovered. Instead, it is “fatal Pomp”, “power” and “Greatness” that are guilty. Line 8 is especially emphatic because its structure suggests that Paris is also a victim, though he does not yet know it, the phrase "Curst with power" not only starting with a forceful reversal of the normal iambic foot, but juxtaposed, via the caesura, with what Oenone is already suffering: “and ruin'd my Content”. But what Behn leaves out is as significant as what she modifies. Because her Oenone blames "Greatness" for her plight, she has no motive for Ovid's generalization on suffering, neatly translated by Cooper as “Misfortunes when deserv'd we may endure, / But when unjustly born, can find no Cure” (98). Behn not only omits this, but also any reference, till as late as line 110, to Helen ("your new Bride” in Cooper's translation quoted above of the first line [97]).

The theme of treacherous courtly power versus pastoral purity and innocence dominates 
Behn's epistle. For example, the 56 lines immediately after this opening passage, which have little or no equivalent in the original, begin with 14 in which Oenone wishes she had known Paris's royal rank when she had first met him, because it would have prevented her from falling in love with him. The sequence goes on to highlight her youth, artlessness and purity. Whereas Ovid's epistle has Oenone assert her chastity by recalling, in a passage near the end of her epistle, how she escaped pursuit by satyrs and had her virginity taken by Apollo only after a struggle in which she tore out some of his hair and scratched his face, Behn has her scorning the shepherds who bring her presents, and "soft, and young as April Flowers" (66) when she first meets Paris.

Behn sounds the same theme in other passages distant from the original. These include a scene in which, after the gods had revealed Paris’s royal birth, "the wisely Grave” urged him to "Change Crooks for Scepters! Garlands for a Crown!” $(152,157)$; the moment of parting, when he was still wavering whether or not to "Refuse a Crown" but chose "the false Idol” in "the great dispute” between “Glory and Love” (169-71); and, most of all, in another passage that has no equivalent in the original in which Oenone attacks courtly corruption directly:

What Stars do rule the Great? no sooner you

Became a Prince, but you were Perjur'd too.

Are Crowns and Falshoods then consistant things?

And must they all be faithless who are Kings?

The Gods be prais'd that I was humbly born,

Even tho’ it renders me my Paris scorn.

For I had rather this way wretched prove,

Than be a Queen and faithless in my Love. (241-48) 
Behn exploits to similar effect a passage that is in the original. In her version, as in Ovid's, Oenone denigrates Helen by claiming that she has sought to represent her seduction by Theseus as abduction. She writes, for example, that Helen "With Theseus from her Country made Escape, / Whilst she miscall'd the willing Flight, a Rape” (255-56). Perhaps borrowing a phrase from Behn, Cooper exaggerates the attack on Helen: "Miscall not thus her ready flight a Rape, / Her wicked self contriv’d the wish’d escape” (106). But this produces a quite different emphasis from the one that Behn has Oenone give when she asks a question of which Ovid gives no hint:

And is it thus Great Ladies keep intire

That Vertue they so boast, and you admire?

Is this a Trick of Courts, can Ravishment

Serve for a poor Evasion of Consent? (259-62)

Behn's Oenone goes on to contrast with this her own pastoral innocence - "How much more happy are we Rural Maids, / Who know no other Palaces than Shades?” (265-66). She abstains from adding the sardonic comment of Ovid’s original that she might have repaid Paris in kind.

Consistently with her presentation of Oenone as a gentle victim of male power games, rather than as a proud, bitter accuser, Behn greatly reduces Oenone’s taunts at Helen’s expense. The only occasion on which her Oenone descends to sarcasm is during the passage just quoted, where, in particular, she charges Helen with a false claim to honour and calls her "but the leavings of a Feast” (254). Elsewhere, she simply omits three harsh or spiteful references to Helen: as dira paelice (60, “cruel mistress”), turpis amica (70, “your shameless girlfriend”); adultera certe est (125, “she is certainly an adulteress”). Here, comparison with Cooper's translation is especially telling. He renders the first phrase as "that curst Strumpet" 
(101); the second, departing further from the source, as "her wanton Head"; and the third, exaggerating still more, as “your Helen is a Whore” (106). But the full extent of Cooper’s misogynism appears in his having Oenone voice what amounts to a diatribe against women:

When once debauch'd, our Sex for ever burn

In lawless fires; Vertue knows no return:

Dishonour never gives a second blow;

And once a Whore she will be ever so. (104)

The first three lines here expand on a couplet and a half in the Latin that states the principle moderately: nulla reparabilis arte / laesa pudicitia est; deperit illa semel ("by no art may virtue once wounded be repaired; it perishes once and for all”; 103-04). Cooper also has Oenone apply to Helen two entirely gratuitous epithets, "curst” (102; the Latin simply has sic Helene doleat [“so may Helen grieve”; 75]), and “Rival” (103). In sharp contrast, Behn’s Oenone nowhere presents Helen in such a light. Her relation to her is much closer to that of Angellica Bianca to Hellena in The Rover, for both figures focus their attention not on the woman for whom they have been forsaken but on the man who has betrayed them.

Even so, Behn has Oenone address Paris much less bitterly than Ovid. She wholly avoids the stereotype of the scorned woman's hellish fury, devoting many lines that have no precedent in the original to a description of the blissful time they spent as lovers, and continuing to call him "lovely” when he has proved "faithless" (224; also 231). Indeed, Behn has Oenone cherish Paris even in the first agonies of her betrayal, writing: "For that dear Name such tenderness inspires, / As turns all Passion to Loves softer Fires” (227-28). Although she retains two of Ovid's similes for Paris's treachery, comparing his fidelity to a leaf blown from a tree in autumn and his lack of fibre to that of decayed corn-ears, she ends by having Oenone recall once more the period of their love and appeal to him to return. 
Addressing him as “charming Paris" (301) and "fair Fugitive” (311) - and, in both phrases, using epithets more often applied by men to women than by women to men - she vows, in a way that again recalls Angellica Bianca, ${ }^{48}$ that all she wants is his love: "Love is the only Dowry I can bring, / And tender Love is all I ask again” (305-06). The result is an epistle centred much more on erotic passion and affection than is Ovid's original. Omitting or playing down the various references in Ovid's poem to Greek and Trojan leaders, and to the mounting political repercussions of Paris’s betrayal, Behn’s poem reflects not a male-centred world, but, especially in its cultivation of pastoral motifs and its avoidance of male formulas about female behaviour, a feminine one.

The relation Oenone establishes with Paris has especially interesting implications in light of Altman's concept of addressee-consciousness. From the point of view of gender, contrasting positions are available for the reader to occupy at each end of a spectrum of possibilities. For example, while one kind of masculine reading might occupy imaginatively the role of Paris, another might read over his shoulder, as it were, with more or less critical detachment. Yet Oenone’s evident sincerity, her distress and, despite the injustices she has suffered, her lack of rancour, would be likely to invite sympathy from both; and, given the inequality between the social and political power of men and women both in the period represented by the poem and in that of its writing, they may also encourage reflection and even self-criticism. Most readings from a feminine subject-position, on the other hand, would be likely to include identifying to a greater or lesser extent with Oenone as the nominal writer. This would invite not only sympathy with her but also recognition that the kind of treatment of which she complains is not limited to the events of a distant legend. In this light, it is also significant that Behn's poem appears to have been the first female-authored heroic epistle, certainly in English - a point of special importance in light of the fact that, though the 
nominal writer of such poems is most often female, the actual author had always been male. ${ }^{49}$ The fact that her authorship was advertised from the start is likely to have thrown the questions about gender that it raises into sharp relief.

Despite the great freedom of Behn's version, it is in the spirit of the original in that, as Peter Knox puts it, the “distinguishing feature of O[vid]'s Heroides is their inspiration from works of literature”. ${ }^{0}$ Just as Ovid, in Knox’s words, “compels his readers to confront his literary models as critics, so to speak", and thereby "causes the reader to separate his reactions from the original model and to question the values represented there” ${ }^{51}$, so too does Behn. In this way, “Oenone to Paris” corresponds to her other adaptations, among them her rewriting of Sir Thomas Killigrew's Thomaso as The Rover, ${ }^{52}$ and, later, her refashioned poems The Golden Age and “A Voyage To The Isle of Love”, as well as her extraordinary mixing of contemporary events and imaginative elaboration in Love Letters Between a Nobleman and his Sister. It is especially significant because it appeared in the first major collection of translations from the classics that were to prove so important to readers without a classical education - among them, of course, many women - in the next hundred or so years. $^{53}$

Behn went even further with an heroic epistle in the name of Ovid himself, stretching the gender boundaries more provocatively still. “Ovid to Julia. A Letter”, first printed in 1685, is a satire on John Sheffield, Earl of Mulgrave, in the spirit of such earlier lampoons as “Ephelia to Bajazet”, probably by Etherege, and “A very heroicall epistle in answer to Ephelia”, probably by Rochester. ${ }^{54}$ Like other poems of the type, it must have circulated in manuscript; a slightly different version, a few lines longer, appears as "Bajazet to Gloriana” in Poems on Affairs of State in 1697 and subsequently in the fourth edition of Dryden's Poetical Miscellanies in $1716 .{ }^{55}$ “Ovid to Julia” has in common with Behn’s “Oenone to 
Paris" the theme of masculine ambition for a crown and the way in which it compromises love. Here the boot is comically on the other foot, as "Ovid" complains that he is a victim of his love for "Julia", which he tries unconvincingly to paint as genuine, rather than of an ambition that, with even less conviction, he claims is not treasonable. As Edward Burns remarks, Behn "performs a doubly witty reversal, as a woman impersonating the male impersonator, himself trapped, as an injured man pleading with the absent and more powerful woman, in a reversal of the kind of situation about which he himself wrote”. ${ }^{56}$ Although the parallels are far from exact, they also carry the implicit warning that her satirical target, like his prototype, risks banishment. “Ovid to Julia” underlines the possibility that “Oenone to Paris” also carries a political message. While that can by no means be excluded, the poem's appearance in a volume of translations makes it more likely that its political implications, concerning the dangers of the court and ambition, and especially their impact on women, are general rather than specific.

It remains to consider what effect Behn's verse epistles may have had on other writers. As Jane Spencer has shown, literary inheritance from a female writer is deeply problematic within a patriarchal, patrilineal culture, and the reputation that male contemporaries were so quick to tarnish made Behn a dubious source to acknowledge. ${ }^{57}$ For these reasons, any influence that her work may have had is particularly difficult to determine. All the same, I suggest that she contributed to four distinct forms of epistolary verse in a way that was substantial enough to have encouraged, provoked or influenced others. First, her familiar epistles to men, along with those between Buckhurst and Etherege, are likely to have fed into the later epistles between Etherege, Middleton and Dryden, and then into Prior's "Epistle to Fleetwood Shephard" and beyond. ${ }^{58}$ Second, her epistolary love poems and her complimentary epistles set a precedent for verse by Sarah Fyge Egerton, Martha Fowke and 
Lady Mary Wortley Montagu, among others, in the next generation. ${ }^{59}$ Third, her version of “Oenone to Paris" set a related precedent for women writers to vary or redefine the conventionally male-authored heroic epistle, as Anne Finch and Elizabeth Rowe were to do after her death, though neither of them took quite such liberties with their originals as she did. ${ }^{60}$ Fourth, her satirical epistles, including, as well as "Ovid to Julia”, “A Letter to the Earl of Kildare”, “To Poet Bavius”, and, if she wrote it, “A Satyr on Doctor Dryden”, were, as part of the lively and often abrasive manuscript culture stimulated by Restoration politics and society, less original. Nevertheless, it is very likely that "Ovid to Julia”, at least, set a precedent for Wortley Montagu, who admired Behn’s work, in her satirical heroic epistles of contemporary life written in the 1720s, "Epistle From Arthur G[ra]y to Mrs M[urra]y” and “Epistle from Mrs. Y[onge] to her Husband”. ${ }^{61}$ Other writers, notably Jane Barker and Elizabeth Mollineux, reacted against the kind of example Behn had set for female-authored epistolary verse. But, whether the influence of Behn's verse epistles was direct or indirect, and whether it is traceable or not, these poems are a distinctive part of her achievement. 


\section{Acknowledgements}

This essay is based on papers presented at the 18th Conference of the Spanish and Portuguese Society for English Renaissance Studies at the University of Cadiz, 8 March 2007, and at the 37th Annual Conference of the British Society for Eighteenth-Century Studies at St Hugh's College, Oxford, 3 January 2008.

1. See esp. Sir Thomas Wyatt, Poems CV (Satire I, “Mine own John Poyntz”), CVII (Satire 3, “A spending hand that alway poureth out”), and CXLV (“Accused though I be, without desert”), Sir Thomas Wyatt: Collected Poems, ed. Joost Daalder (Oxford: Oxford UP, 1975), 100-04, 109-12, 187.

2. For Daniel's earlier Horatian verse epistles (1603), see Certaine Epistles after the Manner of Horace, Written to Divers Noble Personages (London: for Edward Blount); his Ovidian epistle is “A Letter sent from Octauia to her husband Marcus Antonius into Egypt” (1599), first printed in The poeticall essayes of Sam. Danyel (London: by P. Short for Simon Waterson). For discussion of the Ovidian epistle in English literature from this period to the Restoration, see The Rhetoric of Complaint: Ovid's Heroides in the Renaissance and Restoration, a special issue of Renaissance Studies, 22: 3 (June 2008).

3. For discussion of Donne’s verse epistles, see Allen Barry Cameron, “Donne’s Deliberative Verse Epistles”, English Literary Renaissance, 6 (1976): 369-403; Margaret Maurer, “John Donne’s Verse Letters”, Modern Language Quarterly, 37(1976): 234-59; and Ted-Larry Pebworth and Claude J. Summers, “'Thus Friends Absent Speake’: The Exchange of Verse Letters between John Donne and Henry Wotton”, Modern Philology, 81(1984): 36177; for discussion of epistolary verse by Jonson and others, Clay Hunt, “The Elizabethan Background of Neo-Classic Polite Verse”, ELH, 8 (1941): 273-304. 
4. For example, Brome’s Songs and other Poems by Alex. Brome (London: for Henry Brome, 1661) contains a section entitled “Epistles” that includes 60 poems (though those towards the end are not epistolary), among which are "To his University Friend” (16263), “An Epistle to the Meritoriously Honorable Lorde Chiefe Justice of the Kings bench” (199-[2]00), and “To his Friend Mr. I. B. being at London in the Authors retirement” (10911); and Cotton’s epistles in Poems of Charles Cotton, 1630-1687, ed. John Beresford (London: Cobden-Sanderson, 1923), include three to John Bradshaw (257-65) as well as an “Answer” to one of Brome’s epistles (Poems, 394-97; Songs and other Poems, 159-62). Crompton’s Poems (London: by E. C. for Tho. Alsop, 1657) contains “A Letter sent into the Countrey” (34-36); Bradstreet’s The Works of Anne Bradstreet in Prose and Verse, ed. John Harvard Ellis (Gloucester, MA: Peter Smith, 1962), contains “A Letter to her Husband, absent upon Publick employment” (240-41). Margaret Cavendish’s Philosophicall Fancies (London: by Tho. Roycroft, for J. Martin, and J. Allestrye, 1653) contains several short poems entitled "Epistle” that are brief reflections rather than epistles (e.g., "An Epistle to Time”, “An Epistle to my BRAINE”, “AN EPISTLE To a troubled FANCY”, sigs A2v-B1 ${ }^{\mathrm{r}}$ ).

5. G. Gabrielle Starr discusses Behn's use of epistolary form only in general terms and refers to works more in prose than in verse. See "Love’s 'Proper Musick': Lyric Inflection in Behn’s Epistles”, Aphra Behn (1640-1689): Identity, Alterity, Ambiguity, ed. Mary Ann O’Donnell, Bernard Dhuicq and Guyonne Leduc (Paris: L’Harmattan, 2000), 11124. She also discusses what she calls "a lyric influence” in "Oenone to Paris” in "Rereading Prose Fiction: Lyric Convention in Aphra Behn and Eliza Haywood”, Eighteenth-Century Fiction, 12, (1999): 1-18 (9-10).

6. The Standard Habbie, sometimes known as the Burns stanza, consists of six lines, four of eight syllables rhyming together, and two of four syllables rhyming together, the short 
lines ending the stanza with a long line sandwiched between them; some lines may end with hypermetrical light stresses. Its name comes from Allan Ramsay’s reference to the stanza form of a comic elegy by Robert Sempill, first published about 1640, entitled "The Life and Death of Habbie Simson, the Piper of Kilbarchan”. See Helen Damico, “Sources of Stanza Forms Used by Burns”, Studies in Scottish Literature, 12 (1975): 207-19 (208-11).

7. Aphra Behn, The Works of Aphra Behn, Volume 1: Poetry, ed. Janet Todd (London: Pickering, 1992), 12-19, 182-84. All references to Behn’s verse are by line number to this edition and are cited parenthetically in the text.

8. Behn, Poetry 72-73, 166-68, 269-71.

9. Behn, Poetry 61-62, 361, 356.

10. Behn, Poetry 363-64, 299-303, 102-59.

11. Behn, Poetry 231; Aphra Behn, The Poems of Aphra Behn: A Selection (London: William Pickering, 1994), 19-20. Todd expresses confidence in the attribution, Mary Ann O’Donnell doubt. See Behn, Poetry xxiii, 427, and O’Donnell, “Private Jottings, Public Utterances: Aphra Behn’s Published Writings and her Commonplace Book”, Aphra Behn Studies, ed. Janet Todd (Cambridge: Cambridge UP, 1996) 285-309 (297-99). O’Donnell’s doubts about the attribution are convincing, especially as they are supported by evidence of respect and mutual favours between Behn and Dryden in James Anderson Winn, "When Beauty Fires the Blood": Love and the Arts in the Age of Dryden (Ann Arbor: U of Michigan P, 1992), 422-30. All the same, the possibility remains that the poem is by Behn.

12. Aphra Behn, Poems, 47-75. The other sections are entitled "Songs and Satires", “Love Poetry”, “Translation and Paraphrase”, “Prologues and Epilogues”, “Commendation and Elegy” and “Poems of Loyalty”.

13. Behn, Selection, 47-53, 54-56; Poetry 47-52, 56-58. 
14. Behn, Selection, 60-61, 61-62; Poetry 85-86, 92-93.

15. John Rochester, The Works of John Wilmot, Earl of Rochester (Oxford: Oxford UP, 1999), 8-15.

16. Behn, Selection, 64-65, 74; Poetry 94, 288.

17. Rochester, 10-11, 11.

18. Rochester, “Answer to a paper of verses”, 43; “Lines from Chesterfield’s letterbook”, 92; “Artemiza to Chloe”, 63-70; “A very heroical Epistle in answer to Ephelia”, 95-97; “An Epistolary Essay, from M. G. to O. B. upon their mutuall Poems”, 98-101. Love places the non-satirical “Answer to a paper of verses” among "Libertine Lyrics and Shorter Satires”, and “Artemiza to Chloe” among “Longer Discursive Satires”, but the other three poems among "Flytings and Invectives”.

19. John Dryden, “A Letter to Sir George Etherege”, “Canace to Macareus”, “Helen to Paris" (with John Sheffield, Earl of Mulgrave), and "Dido to Aeneas”, The Poems of John Dryden, ed. Paul Hammond and David Hopkins, 5 vols. (London: Longman, 1995-2005), 3: 19-27; 1: 392-96, 397-405, 406-12.

20. Examples of Barker's epistles in her Poetical Recreations (London: for Benjamin Crayle, 1688) are “To Mr. G. P. my Adopted Brother; On the Nigh Approach of his Nuptials” (11-12), “To my Honoured Friend, Mr. E. S—t” (40-42), “To my Brother, Whilst He Was in France” (46-47), and “To my Dear Cousin Mrs. M. T. after the Death of her Husband and Son” (59-61); two epistolary poems in the same collection, "To my Unkind Friend, Little Tom King” (65-69) and “A Second Epistle. To my Honoured Friend Mr E. S.” (70-72), are irregular odes. Mollineux’s posthumously published Fruits of Retirement: Or, Miscellaneous Poems, Moral and Divine (London: by T. Sowle, 1702) contains over 20 verse epistles, most with the word "epistle" or "letter" in their title. 
21. For a detailed argument to this effect, see Bill Overton, The Eighteenth-Century British Verse Epistle (Houndmills: Palgrave, 2007), 21-31.

22. Elizabeth Spearing, “Aphra Behn: The Politics of Translation”, Todd, Aphra Behn Studies, 154-77 (170).

23. Paul Salzman, “Aphra Behn: Poetry and Masquerade”, Todd, Aphra Behn Studies, 109-29 (117).

24. Thanks to Elaine Hobby for a comment on "the Race" that shaped my thinking about the line. It is difficult to know whether Behn's poem inspired or was inspired by Wycherley’s “To the Sappho of the Age, suppos’d to Ly-in of a Love-Distemper, or a Play”, The Complete Works of William Wycherley, ed. Montague Summers, 4 vols. (London: Nonesuch, 1924), 3: 155-56, but the latter is cruder by the same measure as it is less witty. A later poem in the same vein with a male addressee is John Smith’s “An Epistle” in Poems upon Several Occasions (London: for H. Clements, 1713), 241-44.

25. Judith Kegan Gardiner, “Liberty, Equality, Fraternity: Utopian Longings in Behn’s Lyric Poetry”, Rereading Aphra Behn: History, Theory, and Criticism, ed. Heidi Hutner (Charlottesville: UP of Virginia, 1993), 273-300 (291).

26. Janet Gurkin Altman, Epistolarity: Approaches to a Form (Columbus: Ohio State UP, 1982), 211, and Chapter 4, “The Weight of the Reader”. For further application of the concept, see Overton, 73-74, 80-83, 110-16, 170-77, 181-83.

27. As Todd notes, Montagu Summers plausibly suggested that the addressee was Edward Ravenscroft, a fellow dramatist who wrote the Epilogue for Behn's The Town Fop (1677) (Behn, Poetry 395).

28. William C. Dowling, The Epistolary Moment: The Poetics of the EighteenthCentury Verse Epistle (Princeton: Princeton UP, 1991), esp. 7-13, 31-32, 35-36, 60-61, 81. 
29. Gardiner, 291, 292.

30. “To my Lady Morland” is compared with “A Voyage To The Isle of Love” by M. L. Stapleton in Admired and Understood: The Poetry of Aphra Behn (Newark: U of Delaware P, 2004) 191-97.

31. Dryden et al., Ovid's Epistles. Translated by Several Hands (London: by Jacob Tonson, 1680).

32. References to Dryden’s Preface are by line number to the text in Poems, I: 377-91 and are cited parenthetically. Dryden supplied his own version of "Dido to Aeneas" in addition to one without attribution in early editions but by John Somers.

33. Carol Barash, English Women's Poetry, 1649-1714: Politics, Community, and Linguistic Authority (Oxford: Oxford UP, 1996), 114. n. 40. Harriette Andreadis controversially suggests that “Dryden’s preface serves rather to rationalize the coming together of the members of a coterie to display their poetic skills than to make a serious contribution to the theory of translation”. If this is true, it provides a possible alternative explanation for the use of the word "paraphrase" in the title. See "The Early Modern Afterlife of Ovidian Erotics: Dryden’s Heroides”, Renaissance Studies, 22, (2008): 401-16 (406).

34. Cooper's version first appeared in the second edition (London: for Jacob Tonson, 1681), the edition cited here. In subsequent editions, three epistles attributed to Aulus Sabinus were added in 1688; one epistle, the second "Phillis to Demophoon”, by Mr. Floyd, was omitted in 1701 but reinstated in 1716; and three epistles were added in 1712: Pope’s version of “Sapho to Phaon”, Anne Wharton’s of “Penelope to Ulysses”, and John Oldmixon’s of “Deianira to Hercules”. The resulting collection of 29 poems continued to be reprinted frequently until the end of the century, though I have an edition dated 1793 (London: by John Jarvis; not in the English Short Title Catalogue) that omits Behn's. For a fuller account of the 
revisions and additions, including a table of the editions between 1680 and 1720, see Andreadis. In her text (407) Andreadis incorrectly cites the date of first publication of Cooper's 'Oenone to Paris' as 1688, though it is correctly given as 1681 in her Appendix.

35. See Dryden, Poems, 1: 176.

36. Hammond (Dryden, Poems 1: 376), indicates that Dryden is known to have used the translation by Michel de Marolles (1661). Behn may also have done so; it seems unlikely that she would have used the much earlier translation by Octovien Saint-Gelais (1500).

37. Harold Isbell, Ovid: Heroides (London and New York: Penguin, 1990); Daryl Hine, Ovid's Heroines: A Verse Translation of the Heroides (New Haven: Yale UP, 1991).

38. Susan Wiseman misses this point by assuming that Behn was following Ovid. See “‘Perfectly Ovidian’? Dryden’s Epistles, Behn’s ‘Oenone’, Yarico’s Island”, Renaissance Studies, 22, (2008): 417-33 (422).

39. See Ovid, “The Heroides: V”, Ovid, in Six Volumes: I, Heroides and Amores, ed. and trans. Grant Showerman, 2nd ed., rev. by G. P. Goold (Cambridge, MA: Harvard UP; London: William Heinemann, 1977), 57-69 (lines 10, 81-88). References to the Latin are to this edition and are cited parenthetically. Translations are my own, but are based largely on Showerman and Goold's.

40. Aphra Behn, “The Golden Age. A Paraphrase on a Translation out of French”, Poetry 30-35.

41. Behn, Poetry 377.

42. See Heidi Laudien, “Aphra Behn: Pastoral Poet”, Women’s Writing, 12 (2005): 43-58.

43. It is possible that Behn provided more detail on the ground that she could not necessarily assume that all readers would know the myth fully. The effect of calling attention 
to the nature of Paris's choice directly is, however, to emphasize his precise error.

44. Peter E. Knox, ed., Ovid, Heroides: Select Epistles (Cambridge: Cambridge UP, 1995), 149.

45. Barash, 114.

46. John Cooper, 'Oenone to Paris', Ovid's Epistles (1681), 97-108 (97). The Latin is: Perlegis? an coniunx prohibet nova? perlege. All references to Cooper's translation are by page numbers to this edition and are cited parenthetically in the text.

47. There is a possibility that Behn's opening lines were influenced by a prefatory distich found in some manuscripts but rejected by modern editors and most of their predecessors: Nympha suo Paridi quamvis suus esse recuset | mittit ab Ideis verba legenda iugis ("The nymph [Oenone] sends these words from the summits of Ida to her Paris for him to read them, though he refuses to call her his"; Latin text in Knox, $50 \mathrm{n}$ ). Cooper ignores the distich.

48. Compare Angellica Bianca’s challenge to Willmore in Behn, The Rover: "The pay I mean, is but thy love for mine. / Can you give that?” See Aphra Behn, The Rover and Other Plays, ed. Jane Spencer (Oxford: Oxford UP, 1995), 31 (2.2.152-53).

49. See Overton, 133-36.

50. Knox, 18.

51. Knox, 20.

52. See Elaine Hobby, “'No stolen object, but her own’: Aphra Behn’s Rover and Thomas Killigrew’s Thomaso”, Women’s Writing, 6 (1999): 113-27.

53. Garth Tissol remarks that Ovid's Epistles “appears almost by accident to have inaugurated a new era in the English translation of the classics”, and cites their recommendation, in Dryden’s Preface, to a female readership. See Garth Tissol, “Ovid”, The 
Oxford History of Literary Translation in English, Volume 3: 1660-1790, ed. Stuart Gillespie and David Hopkins (Oxford: Oxford UP, 2005), 204-17 (204, 205). See also Stuart Gillespie, "The Early Years of the Dryden-Tonson Partnership: The Background to their Composite Translations and Miscellanies of the 1680s”, Restoration, 12 (1988): 10-19; Claudia N. Thomas, Alexander Pope and his Eighteenth-Century Women Readers (Carbondale and Edwardsville: Southern Illinois UP, 1994), passim; Stuart Gillespie and Penelope Wilson, “The Publishing and Readership of Translation”, Gillespie and Hopkins, Oxford History 3851 (47-49); Stuart Gillespie, “The Developing Corpus of Literary Translation”, Gillespie and Hopkins, Oxford History 123-46 (128).

54. Sir George Etherege, The Poems of Sir George Etherege, ed. James Thorpe (Princeton: Princeton UP, 1963), 9-10; Rochester, Works, 95-97.

55. See Todd’s note in Behn, Poetry, 412-13; Dryden, Poetical Miscellanies, 6 vols. (London: for Jacob Tonson), 2: 80-82.

56. Edward Burns, "Rochester, Lady Betty and the Post-Boy”, Reading Rochester, ed. Edward Burns (Liverpool: Liverpool UP, 1995), 66-83 (75).

57. Jane Spencer, Aphra Behn’s Afterlife (Oxford: Oxford UP, 2000), especially 5059, and ch. 3, “The Sons of Behn”. Spencer observes, for example, that "the woman as writer is not invoked as the mother to a poetic son" (119), and that "The understanding of generative power as a male force has made her influence hard to recognize” (265).

58. For the epistles between Buckhurst and Etherege, see Etherege, 35-45; for those from Etherege to the Earl of Middleton, Etherege, 46-50; for the reply written by Dryden on Middleton’s behalf, Etherege, 51-53, and Dryden, Poems 3: 19-27; for Matthew Prior’s “An Epistle to Fleetwood Shephard, Esq;”, see The Literary Works of Matthew Prior, ed. H. Bunker Wright and Monroe K. Spears, 2 vols. (Oxford: Clarendon, 1959), 1: 85-91. The 
Etherege exchanges are discussed by James How in Epistolary Spaces: English Letter Writing from the Foundation of the Post Office to Richardson's Clarissa (Aldershot, Hants, and Burlington, VT: Ashgate, 2003), ch. 2.

59. See, for example, Fyge Egerton, “To Philaster”, “To Alexis, on his Absence” and “To One who said I must not Love” in Poems on Several Occasions, Together with a Pastoral (London: by J. Nutt, 1703), 34-35, 38-39, 42-43; Martha Fowke (later Sansom), “To CLEON’s Eyes”, A New Miscellany of Original Poems, Translations and Imitations (London: for T. Jauncy, 1720), 264-66, and “To Lady E-H-”, and “The Invitation from a Country Cottage” in Miscellaneous Poems and Translations (London: Samuel Chapman, 1726), 182-86, 191-92; Lady Mary Wortley Montagu, “Epistle [to Lord Bathurst]”, “An Answer to a Love Letter in Verse” and “An Answer to a Lady Advising me to Retirement”, Lady Mary Wortley Montagu: Essays and Poems and Simplicity, a Comedy, ed. Robert Halsband and Isobel Grundy, 2nd edn (Oxford: Clarendon, 1993), 242-44, 244-46, 258-59.

60. See, for example Anne Finch, Countess of Winchilsea, “An Epistle from Alexander to Hephæstion in his Sickness” (unusual not only because it is female-authored, but because it is from one man to another), The Poems of Anne, Countess of Winchilsea, ed. Myra Reynolds (Chicago: U of Chicago P, 1903), 139-41; Elizabeth Rowe, “An EPISTLE from ALEXIAS, a noble Roman, to his wife, whom he left on his wedding-day, with a design to visit the eastern churches”, The Miscellaneous Works in Prose and Verse of Mrs. Elizabeth Rowe, 2 vols. (London: for R. Hett and R. Dodsley, 1739), 1: 150-53; and "Lady JANE GRAY, to Lord GUILFORD DUDLEY”, “Lord Guilford Dudley, to Lady Jane Grey”, and “Rosamond to Henry II”, Letters Moral and Entertaining, 3 pts. (1733; New York: Garland, 1972), 2: 82-84, 85-86; 3: 209-12.

61. Wortley Montagu, Essays and Poems, 221-24, 230-32. Wortley Montagu quotes 
three lines from “To Damon” and adapts a line from “A Voyage To The Isle of Love” in her letters. See Robert Halsband, ed., The Complete Letters of Lady Mary Wortley Montagu, 3 vols. (Oxford: Clarendon, 1965-67), 1: 149; 2: 81; 3: 310, 311. Isobel Grundy cites Behn’s influence on Wortley Montagu in Lady Mary Wortley Montagu (Oxford: Oxford UP, 1999), 18, 19, 310, 343-44, 380. 